\title{
Ionic Currents Underlying Spontaneous Action Potentials in Isolated Cerebellar Purkinje Neurons
}

\author{
Indira M. Raman and Bruce P. Bean \\ Department of Neurobiology, Harvard Medical School, Boston, Massachusetts 02115
}

Acutely dissociated cell bodies of mouse Purkinje neurons spontaneously fired action potentials at $\sim 50 \mathrm{~Hz}\left(25^{\circ} \mathrm{C}\right)$. To directly measure the ionic currents underlying spontaneous activity, we voltage-clamped the cells using prerecorded spontaneous action potentials (spike trains) as voltage commands and used ionic substitution and selective blockers to isolate individual currents. The largest current flowing during the interspike interval was tetrodotoxin-sensitive sodium current (approximately $-50 \mathrm{pA}$ between -65 and $-60 \mathrm{mV}$ ). Although the neurons had large voltage-dependent calcium currents, the net current blocked by cobalt substitution for calcium was outward at all times during spike trains. Thus, the electrical effect of calcium current is apparently dominated by rapidly activated calcium-dependent potassium currents. Under current clamp, all cells continued firing spontaneously (though $\sim 30 \%$ more slowly) after block of T-type calcium current by mibefradil, and most cells continued to fire after block of all calcium current by cobalt substitution. Although the neurons possessed hyperpolarization-activated cation current $\left(I_{\mathrm{h}}\right)$, little current flowed during spike trains, and block by $1 \mathrm{~mm}$ cesium had no effect on firing frequency. The outward potassium currents underlying the repolarization of the spikes were completely blocked by $1 \mathrm{~mm}$ TEA. These currents deactivated quickly $(<1$ $\mathrm{msec}$ ) after each spike. We conclude that the spontaneous firing of Purkinje neuron cell bodies depends mainly on tetrodotoxin-sensitive sodium current flowing between spikes. The high firing rate is promoted by large potassium currents that repolarize the cell rapidly and deactivate quickly, thus preventing strong hyperpolarization and restoring a high input resistance for subsequent depolarization.

Key words: cerebellum; sodium current; calcium current; potassium current; $\mathrm{I}_{h}$; spike; pacemaking; pacemaker
Brain activity must begin somewhere, and some neurons spontaneously fire action potentials even in the absence of external stimuli. Such pacemaking activity is seen in a wide variety of neurons in the CNS (Llinás, 1988), including thalamic neurons (Jahnsen and Llinás, 1984; McCormick and Pape, 1990), neurons of the suprachiasmatic nucleus (Pennartz et al., 1997), neurons releasing monoamine transmitters such as dopamine, serotonin, histamine, and norepinephrine (Williams et al., 1984; Grace and Onn, 1989; Yung et al., 1991; Uteshev et al., 1995; Bayliss et al., 1997), and GABAergic interneurons of the hippocampus and the cerebral and cerebellar cortex (Alger and Nicoll, 1980; Salin and Prince, 1996; Häusser and Clark, 1997).

The ionic mechanisms underlying spontaneous firing are incompletely understood. In pacemaker cells of the heart, a hyperpolarization-activated cation current $\left(I_{\mathrm{h}}\right)$ is important for spontaneous activity (DiFrancesco, 1993). This current also contributes to the spontaneous activity of some central neurons (Pape, 1996). Low-threshold, T-type calcium channels also contribute to the spontaneous activity of some excitable cells, including sinoatrial cells, neuroendocrine cells, and various central neurons (Huguenard, 1996). Of central neurons that fire spontaneously, the most thorough investigation has been made of thalamic neurons, where both $I_{\mathrm{h}}$ and T-type calcium channels play important roles (Jahnsen and Llinás, 1984; McCormick and Pape, 1990). However, in other neurons, spontaneous firing does not

\footnotetext{
Received Sept. 22, 1998; revised Dec. 17, 1998; accepted Dec. 21, 1998.

This work was supported by National Institutes of Health (NS36855). I.M.R. was supported by National Research Service Award NS10396.

Correspondence should be addressed to Indira M. Raman, Department of Neurobiology and Physiology, Northwestern University, 2153 North Campus Drive, Evanston, IL 60208.

Copyright (C) 1999 Society for Neuroscience $\quad 0270-6474 / 99 / 191663-12 \$ 05.00 / 0$
}

require $I_{\mathrm{h}}$ or calcium current. In some, tetrodotoxin-sensitive sodium current appears to be important in generating spontaneous depolarizations as well as in forming spikes (Alonso and Llinás, 1989; Pennartz et al., 1997; Feigenspan et al., 1998).

Cerebellar Purkinje neurons in vivo show regular, spontaneous firing (Bell and Grimm, 1969; Latham and Paul, 1971). Studies with in vitro preparations suggest that this results from intrinsic membrane properties. Spontaneous firing can be maintained in cerebellar slice preparations (Hounsgaard, 1979; Llinás and Sugimori, 1980b; Häusser and Clark, 1997) and in cultured Purkinje neurons (Gruol and Franklin, 1987), even when synaptic activity is blocked. Early studies suggested that spontaneous firing was caused by calcium action potentials arising in the dendritic tree (Llinás and Sugimori, 1980b). Surprisingly, however, cultured Purkinje neurons were found to fire spontaneously even before formation of dendrites (Gruol et al., 1991), and subsequent work has shown that spontaneous firing is preserved even in acutely isolated cell bodies of Purkinje neurons (Nam and Hockberger, 1997; Raman and Bean, 1997).

Most efforts to understand how different ionic conductances interact to produce spontaneous activity in central neurons have relied on computer models. Here we have taken advantage of the ability to obtain high-quality voltage-clamp recordings from isolated Purkinje neurons to take a direct experimental approach. By using previously recorded spontaneous action potentials as voltage commands, we measured the ionic currents that flow during spontaneous activity, using pharmacology and ionic substitution to identify components of current from particular channel types.

\section{MATERIALS AND METHODS}

Cell preparation. Experiments were performed on cerebellar Purkinje neurons enzymatically isolated as previously described (Mintz et al., 
1992; Raman et al., 1997). Black Swiss mice (postnatal day 14-20) were anesthetized with methoxyflurane before decapitation, and the vermal layer of the cerebellum was removed and minced in ice-cold, oxygenated dissociation solution containing (in $\mathrm{mm}$ ): $82 \mathrm{Na}_{2} \mathrm{SO}_{4}, 30 \mathrm{~K}_{2} \mathrm{SO}_{4}, 5$ $\mathrm{MgCl}_{2}, 10 \mathrm{HEPES}, 10$ glucose, and $0.001 \%$ phenol red (buffered to $\mathrm{pH}$ 7.4 with $\mathrm{NaOH}$ ). The tissue was then incubated for $7 \mathrm{~min}$ in $10 \mathrm{ml}$ of dissociation solution containing $3 \mathrm{mg} / \mathrm{ml}$ protease XXIII (Sigma, St. Louis, MO), pH 7.4 with $\mathrm{NaOH}$, at $37^{\circ} \mathrm{C}$, with oxygen blown over the surface of the fluid. The tissue was then washed in warmed, oxygenated dissociation solution containing $1 \mathrm{mg} / \mathrm{ml}$ bovine serum albumin and 1 $\mathrm{mg} / \mathrm{ml}$ trypsin inhibitor, and then maintained in Tyrode's solution containing (in mM): $150 \mathrm{NaCl}, 4 \mathrm{KCl}, 2 \mathrm{CaCl}_{2}, 2 \mathrm{MgCl}_{2}, 10 \mathrm{HEPES}, 10$ glucose, $\mathrm{pH} 7.4$ with $\mathrm{NaOH}$, at room temperature, with oxygen blown over the surface of the fluid. Tissue was withdrawn as needed and triturated with a fire-polished Pasteur pipette to liberate individual neurons. Purkinje cells were identified by their large diameter and characteristic pear shape attributable to the stump of the apical dendrite. Cells were used between $30 \mathrm{~min}$ and $5 \mathrm{hr}$ of trituration. Although long dendrites were rarely seen, some dendritic membrane may have been incorporated into the isolated neurons.

Current-clamp experiments. Recordings were made with an Axoclamp 2B amplifier (Axon Instruments, Foster City, CA). Borosilicate pipettes (3-5 M $\Omega$ ) were filled with an internal solution containing (in $\mathrm{mM}$ ): 122 $\mathrm{KCH}_{3} \mathrm{O}_{3} \mathrm{~S}, 9$ EGTA, 9 HEPES, $1.8 \mathrm{MgCl}_{2}$, 14 Tris-creatinePO 4 MgATP, and 0.3 TrisGTP, buffered to pH 7.4 with KOH. This solution was designed to approximate physiological ionic conditions. The calciumbuffering properties are likely to differ from endogenous conditions (Fierro and Llano, 1996), but it seems unlikely that this would greatly affect firing properties because even complete block of calcium entry generally had small effects. The control external solution was Tyrode's solution. Voltage values were corrected for a $-5 \mathrm{mV}$ junction potential between these solutions. Spontaneous action potentials were recorded in the absence of injected current. For the voltage-clamp/current-clamp switch for the experiments shown in Figures 13 and 14 , cells were voltage-clamped in the single-electrode continuous voltage-clamp mode for 4-6 sec (depending on the protocol) and then the clamp was released manually by switching into bridge mode.

Voltage-clamp experiments. Whole-cell recordings were made at room temperature with an Axopatch 200B amplifier (Axon Instruments). For all experiments except those of Figure 8 (calcium currents), borosilicate pipettes (1-3 M $\Omega$ ) were filled with the same internal solution as for the current-clamp experiments. For the experiments of Figure 8, pipettes contained (in mM): $117 \mathrm{CsCl}, 9$ EGTA, 9 HEPES, $1.8 \mathrm{MgCl}_{2}$, 14 Triscreatine $\mathrm{PO}_{4}, 4 \mathrm{MgATP}$, and 0.3 TrisGTP, buffered to $\mathrm{pH} 7.4$ with CsOH.

Capacitative current was removed using the capacity compensation circuitry of the patch-clamp amplifier. Sometimes capacity compensation was imperfect, as indicated by small transients at the beginning of step voltage pulses. Series resistance was compensated by $85-95 \%$.

Solution changes. Cells were lifted and placed in front of a row of flow pipes. The control external solution was normal Tyrode's solution, referred to as "calcium Tyrode's solution." Other solutions included "cobalt Tyrode's solution" in which $2 \mathrm{mM} \mathrm{CoCl}_{2}$ was substituted for the 2 mM $\mathrm{CaCl}_{2}$, and TTX, TEA, and Cs in which $300 \mathrm{~nm}$ TTX (except where lower concentrations are indicated), $1 \mathrm{~mm}$ tetraethylammonium chloride, or $1 \mathrm{~mm} \mathrm{CsCl}$, respectively, was added to the calcium or cobalt Tyrode's solution. For isolation of sodium, potassium, calcium, and $I_{\mathrm{h}}$ currents, protocols were repeated in Tyrode's solution plus the relevant blocker, and these recordings were subtracted from the control records. Although raw traces are illustrated in some of the figures, quantitative measurements were made only on subtracted records, which isolate the ionic current of interest.

All experiments were performed at room temperature $\left(20-24^{\circ} \mathrm{C}\right)$

Drugs. Mibefradil and nimodipine were kindly provided by Dr. Eric Ertel (Hoffmann-La Roche, Basel, Switzerland) and Dr. Richard McCarthy (Miles Laboratories, West Haven, CT), respectively. All other chemicals were obtained from Sigma, except $\omega$-conotoxin-GVIA (Peninsula Laboratories, Belmont, CA), $\omega$-conotoxin-M VIIC (Bachem California, Torrance, CA), and $\omega$-agatoxin-IVA (Peptides International, Louisville, KY).

Acquisition and analysis. Data were acquired with a Digidata 1200 interface and pCLAMP software (Axon Instruments) and analyzed with pClamp and Origin (Microcal Inc., Northampton, MA). Data are presented as mean \pm SEM.
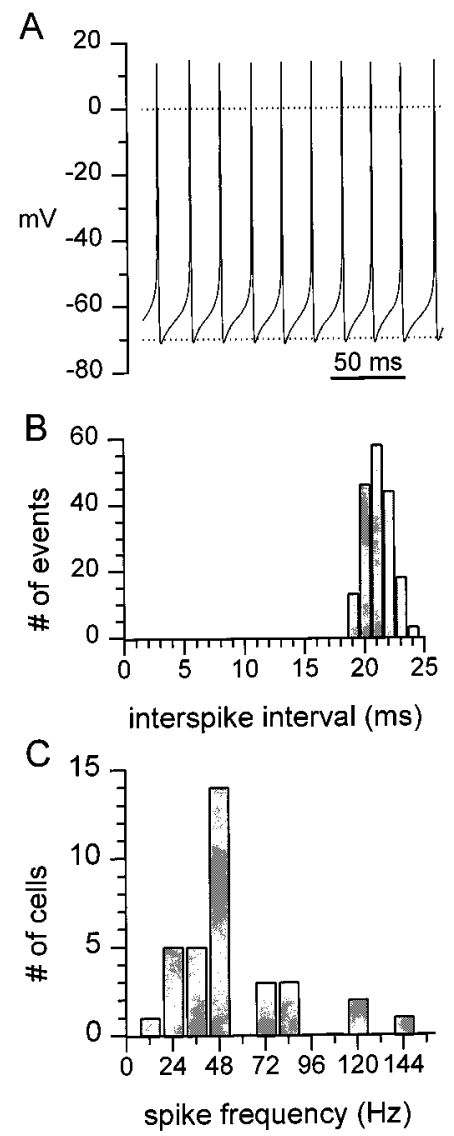

Figure 1. Properties of spontaneous firing in isolated Purkinje neurons. $A$, Spontaneous action potentials recorded from a Purkinje neuron bathed in physiological saline. In this and all current-clamp traces (except voltage-current relations), dotted lines indicate 0 and $-70 \mathrm{mV}$. This record of spontaneous firing was used as the spike train command potential for voltage-clamp experiments. $B$, Interspike interval histogram for the cell in $A$. The mean \pm SD was $20.5 \pm 1.1 \mathrm{msec}$ (182 intervals), giving a coefficient of variation of 0.05 . $C$, Histogram of spontaneous firing frequencies of 34 Purkinje neurons.

\section{RESULTS}

\section{Firing properties of isolated Purkinje neurons}

All isolated Purkinje neurons fired spontaneously (with no injected current) when studied in current clamp with physiological solutions. Each cell fired at an extremely regular rate, with frequencies across cells ranging from 17 to $148 \mathrm{~Hz}$. The neuron whose action potentials are illustrated in Figure $1 A$ fired at 47.5 $\mathrm{Hz}$, with interspike intervals over 182 action potentials varying by only a few milliseconds (Fig. $1 B$ ). In 34 cells, the median firing frequency was $47 \mathrm{~Hz}$, and the mean was $54 \pm 5 \mathrm{~Hz}$ (Fig. 1C). The most negative voltage reached between action potentials was $-71 \pm 1 \mathrm{mV}$, and the peak of the spikes was $+11 \pm 2 \mathrm{mV}$.

\section{Voltage-clamp experiments: sodium currents}

We studied the neurons under voltage-clamp to characterize the ionic currents underlying spontaneous firing. In voltage-clamped neurons, currents were elicited both by step depolarizations and by using a previously recorded train of spontaneous action potentials ("spike train") as the command voltage-clamp waveform. We identified particular ionic currents present in the cells by conventional measurements of voltage dependence and kinetics during the step depolarizations, together with ionic substitution and 
blocking agents to isolate individual components of current. The spike train protocol enabled us to make direct measurements of pharmacologically isolated currents flowing at each point in the cycle of pacemaking.

In principle, the record of a cell's own spontaneous firing could be used as the command voltage for that cell. Then the total current (ionic current plus capacitative current) flowing in response to the command voltage should be zero at all times during the cycle, with ionic current and capacitative current equal and opposite. This experiment has been accomplished in cardiac sinoatrial cells by switching a patch-clamp amplifier between current-clamp and voltage-clamp modes (Doerr et al., 1989; Zaza et al., 1997). This was not possible in Purkinje neurons, where action potentials are faster and currents are bigger. We found that the voltage recorded by the patch-clamp amplifier in currentclamp mode was significantly distorted (with an artifactually negative trough potential and artifactually positive spike peak) compared with that recorded using an amplifier with a voltagefollower head stage. The reasons for the distortion of currentclamp recordings using a patch-clamp amplifier have been discussed (Magistretti et al., 1996).

In making voltage-clamp recordings, we therefore used as command voltage a record of spontaneous firing previously recorded in a different cell using a voltage follower amplifier. We selected a record of spontaneous firing from a cell that had a firing frequency near the median value across cells. Because we were interested in ionic currents flowing during the spike train, we removed the capacitative current using the capacity compensation circuitry of the patch-clamp amplifier. We then used selective blocking agents to isolate individual components of ionic current.

In identifying individual currents active during cycles of pacemaking, we first focused on voltage-dependent sodium current. All voltage-dependent sodium current in Purkinje neurons is blocked by TTX (Song and Narahashi, 1996; Nam and Hockberger, 1997; Raman and Bean, 1997; Kay et al., 1998), and the high selectivity and complete reversibility of TTX make it an ideal tool for isolating a single component of current elicited in response to a complex waveform. Figure 2 shows currents evoked by step depolarizations from a holding potential of $-60 \mathrm{mV}(A)$ and by the spike train protocol $(B)$. These voltage-clamp experiments used the same internal (primarily $\mathrm{KCH}_{3} \mathrm{O}_{3} \mathrm{~S}$ ) and external (calcium Tyrode's) solutions as for the current-clamp recordings, designed to approximate physiological ionic conditions. Voltage steps positive to $-55 \mathrm{mV}$ activated inward current, which reached a maximum for steps near $0 \mathrm{mV}$ and was followed by outward current for steps beyond $-30 \mathrm{mV}$. TTX (300 nM) completely blocked the inward current evoked by steps to all voltages, leaving large outward currents. With the spike train waveform (Fig. 2B), under control conditions there was a large inward current that reached a peak during the upstroke of each spike, followed by an outward current that was largest during the falling phase of each spike. TTX completely blocked the inward current elicited by the spike train. Thus, the upstroke of the action potentials is caused entirely by TTX-sensitive sodium current, with no contribution of voltage-dependent calcium current.

In Figure 2, the peak sodium current during the action potential upstroke $(-4.0 \mathrm{nA}$, reached at a voltage of $-34 \mathrm{mV})$, was smaller than the peak sodium current elicited by voltage steps $(-5.6 \mathrm{nA}$, reached at a voltage of $-15 \mathrm{mV})$. Because the steps were delivered from a holding potential of $-60 \mathrm{mV}$, more positive than the main part of the interspike interval, it is unlikely that the smaller current during the spike reflects more initial inacti-

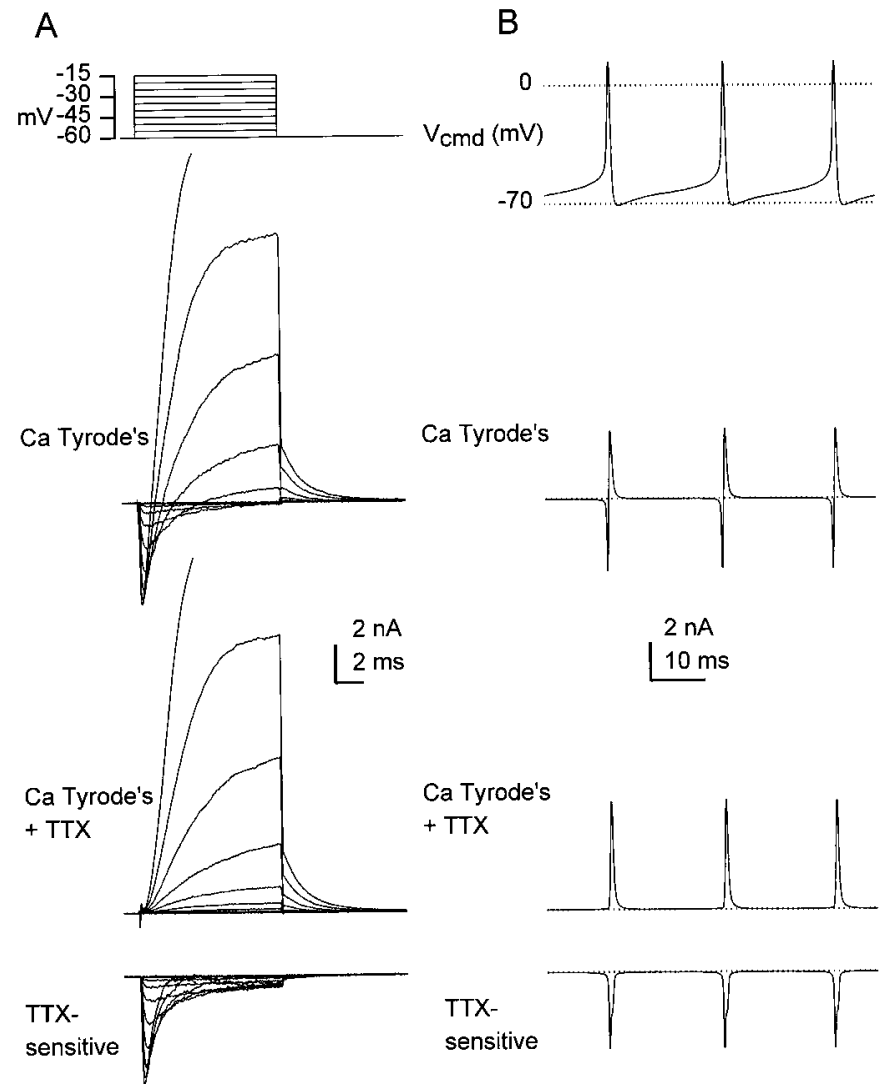

Figure 2. Sodium currents during voltage steps and spikes in Purkinje cell bodies. $A$, Holding potential, $-60 \mathrm{mV}$. Steps were -60 to $-15 \mathrm{mV}$ in $5 \mathrm{mV}$ increments (top panel). Raw current evoked by step depolarizations in calcium Tyrode's (top) and in calcium Tyrode's with 300 nM TTX (middle). The difference between the two sets of traces shows the TTXsensitive sodium current (bottom). $B$, Sodium current evoked by a train of action potentials. Same cell as in $A$. The spike train protocol was used as the voltage-clamp command waveform (top panel). Raw and subtracted traces as in $A$. The command waveform was presented five times with a 1 sec interval, and the resulting currents were averaged. In this and all figures of currents evoked by the spike train protocol, the dotted line indicates $0 \mathrm{pA}$. To facilitate comparison, vertical gain is the same as that in $A$.

vation. Most likely, activation of sodium channels is not complete during the upstroke of the action potential. Even more striking is the difference in magnitude of the outward current elicited by a spike compared with that activated by $12 \mathrm{msec}$ steps. In the experiment shown in Figure 2, the peak outward current during the spikes (which reach a peak of $+14 \mathrm{mV}$ ) is $5.7 \mathrm{nA}$, whereas outward current elicited by the steps exceeds $20 \mathrm{nA}$ for a step to $-15 \mathrm{mV}$. Only a very small fraction of available potassium conductance is activated during a spike.

In many cells, it was impossible to adequately voltage clamp the sodium currents. When elicited from a holding potential of -90 $\mathrm{mV}$, sodium currents were almost always larger than $20 \mathrm{nA}$, the level at which the headstage amplifier reached saturation, and they often exceeded $20 \mathrm{nA}$ even from a holding potential of -65 $\mathrm{mV}$, where nearly half the channels are inactivated (Raman and Bean, 1997). We assessed quality of clamp by a smoothly graded increase in the sodium currents evoked in the region of -50 to $-20 \mathrm{mV}$ by steps in $5 \mathrm{mV}$ increments. By this criterion, we obtained good clamp of sodium current in five neurons for which we could obtain a complete series of recordings with and without TTX. The neuron whose records are shown in Figure 2 is one of 
these. A second criterion for good voltage clamp was the behavior of the TTX-sensitive currents elicited by step depolarizations, obtained by subtracting currents remaining in TTX from control records (Fig. $2 A$, bottom panel). In cells with imperfect voltage control, the expected transient inward current was followed by small transient outward currents. These outward currents are expected from small errors in voltage control-for example, those caused by incompletely compensated series resistance. In control solution, the large inward sodium current produces an additional depolarization by its flow through the series resistance, and this larger depolarization activates a larger outward current than that activated by the same nominal voltage step without inward sodium current. Because the outward current during a 12 msec step depolarization changes dramatically for a $5 \mathrm{mV}$ increment in test voltage ( $>5 \mathrm{nA}$ between -20 and $-15 \mathrm{mV}$ for the cell in Fig. 2), a change in outward current with TTX application is a very sensitive assay for voltage-clamp errors. In the five neurons with optimal voltage control, either there were no TTX-sensitive outward currents (as in Fig. 2) or they were small enough to be consistent with voltage errors of only $1-2 \mathrm{mV}$.

Subtracting the currents elicited by the spike train before and after TTX application yields the sodium current flowing during the spontaneous activity (Fig. $2 B$, bottom). In the five neurons with optimal voltage control, this current was inward throughout the spike train. In these five cells, the peak sodium current during the upstroke of a spike was $-6.0 \pm 1.2 \mathrm{nA}$. This can be compared with the ionic current flowing during the upstroke of spontaneous spikes, which can be calculated from the product of cell capacitance and $d V / d t$, the time derivative of voltage (Hodgkin and Huxley, 1952). The maximal rate of depolarization was $255 \pm 25$ $\mathrm{mV} / \mathrm{msec}$, which would correspond to $6.4 \pm 0.6 \mathrm{nA}$ for a typical 25 $\mathrm{pF}$ cell. Thus, the measured sodium current can account well for the upstroke velocity of spontaneous action potentials.

Figure 3 shows at higher resolution the TTX-sensitive sodium current elicited by the spike train. There is sodium current flowing at all times between spikes (Fig. 3A,B). The current between spikes had a characteristic kinetic feature consisting of a secondary rise in current that occurred when the action potential reached its trough (Fig. $3 C$ ). This is reminiscent of the "resurgent" sodium current that occurs on repolarization after strong depolarizations in both rat and mouse Purkinje neurons (Raman and Bean, 1997; Raman et al., 1997; Kay et al., 1998). The decay of this secondary rise in current is consistent with the decay kinetics of resurgent current (time constant of $\sim 3 \mathrm{msec}$ at -70 $\mathrm{mV}$ ) (Raman and Bean, 1997). After the decay of this component, the interspike sodium current typically reached a minimum near $-65 \mathrm{mV}$ and then increased in a regenerative manner. In the five cells with optimal voltage clamp, the mean TTX-sensitive sodium current was $-22 \pm 3 \mathrm{pA}$ between -70 and $-65 \mathrm{mV}$, and $-48 \pm 4 \mathrm{pA}$ between -65 and $-60 \mathrm{mV}$. There was a smooth transition from the small sodium current between spikes to the large current during the upstroke of a spike.

\section{Calcium currents and potassium currents}

We next examined the possible contribution of voltage-dependent calcium channels to spontaneous firing. Isolated Purkinje neurons have large voltage-dependent calcium currents (Kaneda et al., 1990; Regan, 1991; Mintz et al., 1992; McDonough and Bean, 1998), which often exceeded $1 \mathrm{nA}$ with physiological external calcium (e.g., see Fig. 8). Replacement of calcium by cobalt rapidly and reversibly blocks calcium current through all types of calcium channels. To examine calcium currents in physiological
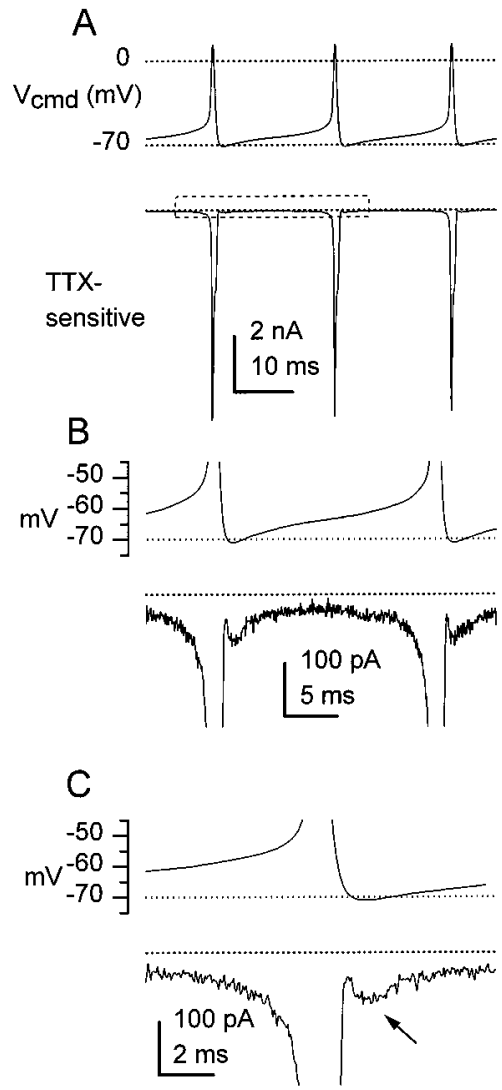

Figure 3. Kinetics of sodium currents evoked by spike train protocol. $A$, Command voltage and TTX-sensitive sodium currents (different cell than in Fig. 2). Currents were obtained by subtraction as in Figure 2. B, Display at faster time base and greater magnification of command voltage and current response within dashed lines in $A$. C, First $13 \mathrm{msec}$ of the trace in $B$. The arrow indicates the bump of sodium current that occurs when the action potential command reaches its trough.

solutions, we recorded currents in calcium Tyrode's solution + 300 nм TTX (Fig. 4C,D) and in cobalt Tyrode's solution +300 nM TTX (Fig. 4E,F). The difference between the traces with calcium and with cobalt consists of calcium current plus any currents activated by the calcium entry. Calcium currents in Purkinje cells are large and sustained (Regan, 1991; Mintz et al., 1992). However, during the step depolarizations in these solutions, the net cobalt-sensitive current had only a barely detectable phase of inward current that is rapidly overwhelmed by outward current (Fig. 4G). This outward current is likely to be calciumactivated potassium current, because the tail currents after step depolarizations reversed near $E_{\mathrm{K}}$ and changed as expected on increasing external potassium from 4 to $16 \mathrm{~mm}$ (data not shown). Remarkably, in response to the spike train command, the current blocked by cobalt substitution was net outward at all times during spikes, and it decayed to zero between spikes (Fig. 4H,I). Thus, at no time during the pacemaking cycle does calcium entry appear to have a net depolarizing effect.

Low concentrations of external TEA are effective in blocking some potassium currents in Purkinje neurons (Gähwiler and Llano, 1989; Gruol et al., 1991). Accordingly, we assessed the outward currents' sensitivity to $1 \mathrm{~mm}$ TEA. Figure 5 shows currents from the same cell illustrated in Figure 4. In Tyrode's solution containing $1 \mathrm{~mm}$ TEA (as well as $300 \mathrm{~nm}$ TTX), step depolarizations elicited an early inward phase of current that 

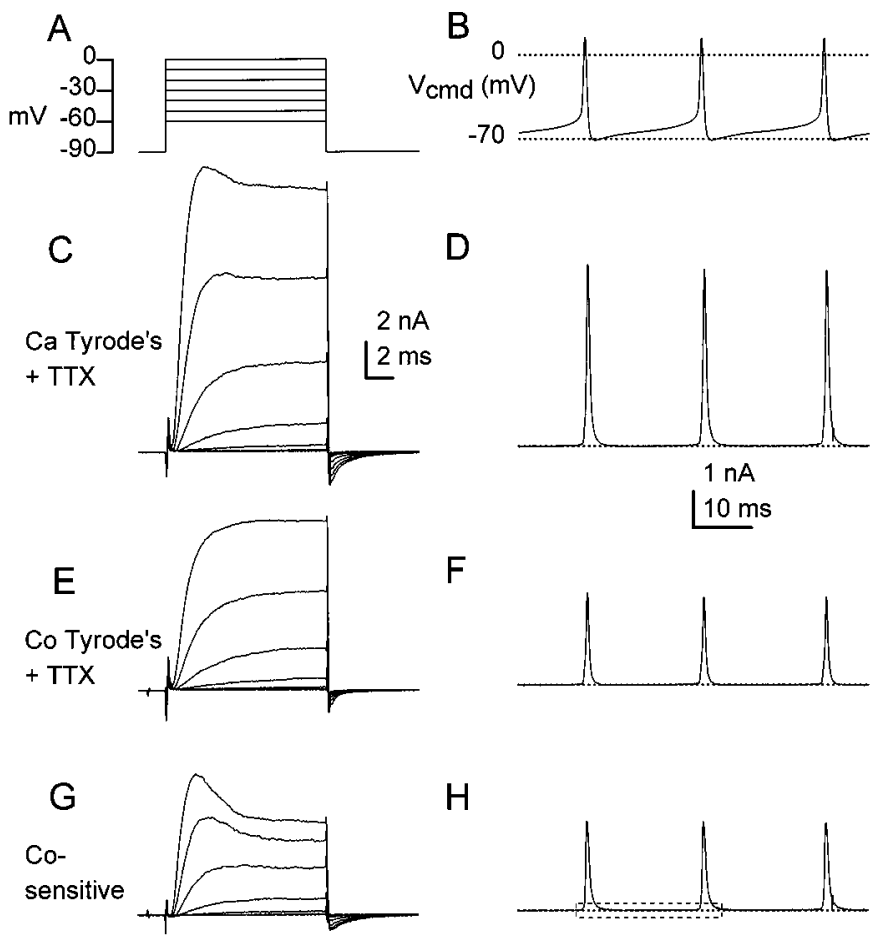

$\mathrm{H}$

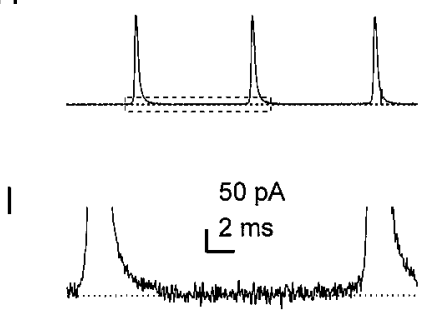

Figure 4. Calcium-dependent and -independent currents during steps and spikes in a Purkinje cell body. $A$, Step voltage protocol for $C, E$, and $G$; holding potential, $-90 \mathrm{mV}$; steps, -60 to $0 \mathrm{mV}, 10 \mathrm{mV}$ increments. $B$, Spike train protocol for $D, F$, and $H$. $C, D$, Raw currents evoked in calcium Tyrode's with 300 nм TTX. Calibration in $C$ also applies to $E$ and $G$. Calibration in $D$ also applies to $F$ and $H$, and vertical gain is twice that in $C, E$, and $G$, to facilitate comparison. $E, F$, Currents evoked in cobalt Tyrode's with 300 nM TTX. $G, H$, Cobalt-sensitive current, obtained by subtraction of records in cobalt Tyrode's from those in calcium Tyrode's. $I$, Amplification of current within dashed lines in $H$, to illustrate the lack of cobalt-sensitive current in the interspike interval.

quickly became outward, presumably consisting of calcium current followed by TEA-resistant potassium current. With calcium Tyrode's solution, $1 \mathrm{~mm}$ TEA reduced the peak outward current elicited by a step to $0 \mathrm{mV}$ by $83 \pm 2 \%$, and the steady-state current measured at the end of the $12 \mathrm{msec}$ step by $63 \pm 3 \%(n=$ 8) (Fig. $5 C$ vs $4 C$ ). When recordings were repeated in cobalt Tyrode's solution, the inward current disappeared, and the outward currents were reduced in amplitude and activated at a much slower rate (Fig. 5E).

Although TEA blocked outward currents elicited by step depolarizations only partially, it abolished all outward current elicited by the spike train command (Fig. $5 D$ ), leaving only an inward current that could be blocked by cobalt (Fig. $5 F$ ). This observation was consistent across cells $(n=8)$. Thus, despite the multiple types of potassium currents present in the cells, those evoked during a spike are all TEA sensitive.

The TEA-sensitive currents measured in calcium therefore represent the total potassium current evoked by the spike train command. The potassium current activated by each spike was largest during the falling phase of the spike, as expected, and it then decayed very rapidly on repolarization (Fig. $5 H, J)$. Fitting
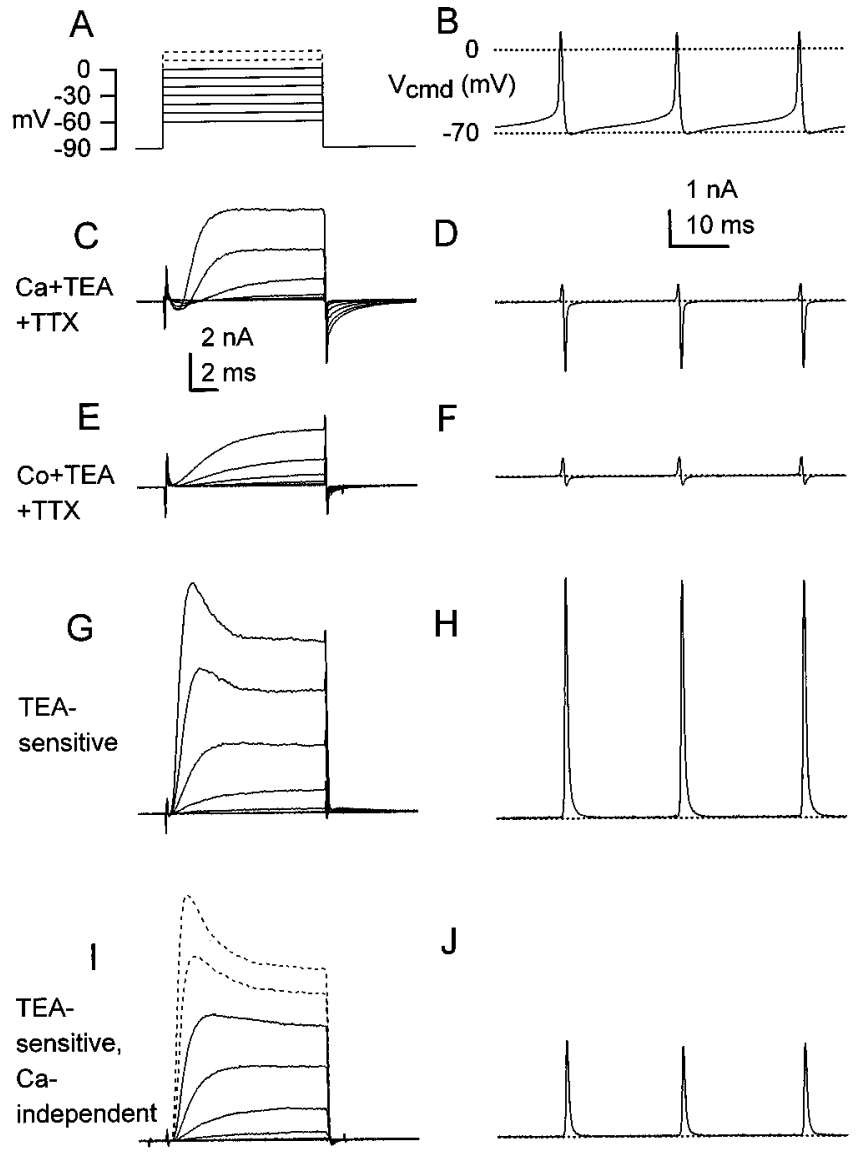

Figure 5. TEA-sensitive currents during steps and spikes in a Purkinje cell body. Same cell as in Figure 4. Calibrations for responses to step protocol $(A)$ and spike train protocol $(B)$ are the same as in Figure 4. Voltage protocol in $A$ applies to $C, E, G$, and $I$. Steps indicated by the dashed lines are to +10 and $+20 \mathrm{mV}$ and apply only to the dashed traces in $I$. Voltage protocol in $B$ applies to $D, F, H$, and $J$. $C, D$, TEA-insensitive currents. Raw currents evoked in calcium Tyrode's with 1 mM TEA and 300 nм TTX. $E, F$, TEA-insensitive, calcium-independent currents. Raw traces evoked in cobalt Tyrode's with 1 mM TEA and 300 nM TTX. $G, H$, Total TEA-sensitive current. Currents in $C$ and $D$ subtracted from those in Figure $4, C$ and $D$, respectively. $I, J$, TEA-sensitive, calciumindependent current. Currents in $E$ and $F$ subtracted from those in Figure 4, $E$ and $F$, respectively. The dashed traces in $I$ show currents evoked at more positive potentials and illustrate the rapidly inactivating component of TEA-sensitive calcium-independent current.

the decay of the total TEA-sensitive current with a single exponential gave a time constant $(\tau)$ of $0.28 \pm 0.01 \mathrm{msec}(n=6)$, and the total potassium current between spikes was essentially zero $(1.1 \pm 1.8 \mathrm{pA}, n=6$, measured between -65 and $-60 \mathrm{mV})$. The decay of potassium current must reflect rapid and complete deactivation of channels and not simply a decrease in driving force, because the troughs of the spike train are still $25 \mathrm{mV}$ positive to $E_{\mathrm{K}}$.

In response to step depolarizations, both calcium-dependent and calcium-independent components of the TEA-sensitive current show rapid, partial inactivation (Fig. 5G,I). The total TEAsensitive current inactivates by $35 \pm 3 \%$ during the $12 \mathrm{msec}$ step $(n=8)$. Consistent with inactivation of calcium-dependent potassium current, $100 \mathrm{nM}$ iberiotoxin blocked a current that inactivated partially with a time constant of $3 \mathrm{msec}$ at $0 \mathrm{mV}(n=4$; data not shown). The TEA-sensitive current recorded in cobalt (Fig. 5I) shows rapid activation and a rapidly inactivating phase 

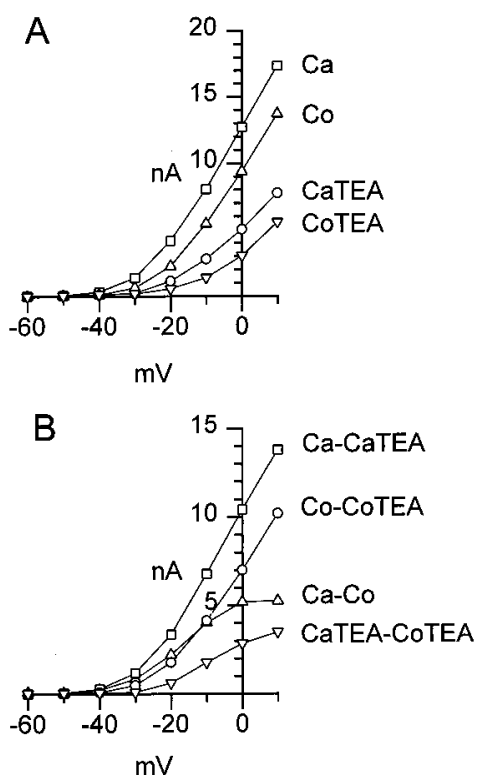

Figure 6. Current-voltage relations for outward currents evoked by step depolarizations. All currents were recorded in $300 \mathrm{~nm}$ TTX. Data from the traces illustrated in Figures 4 and 5. $\mathrm{Ca}$, Calcium Tyrode's; $\mathrm{Co}$, cobalt Tyrode's; CaTEA, calcium Tyrode's + 1 mM TEA; CoTEA, cobalt Tyrode's +1 mM TEA. Current was measured as the maximal outward current during the $12 \mathrm{msec}$ step. $A$, Raw currents in the solutions indicated. $B$, Difference currents for the solutions indicated.

positive to $0 \mathrm{mV}$, with an exponential decay constant of $2.3 \pm 0.2$ msec at $+10 \mathrm{mV}(n=7)$, which decreased to $1.6 \pm 0.3 \mathrm{msec}$ at $+30 \mathrm{mV}(n=4)$.

Figure 6 shows the voltage dependence of various components of potassium current. Stepping from $-90 \mathrm{mV}$, the first measurable currents $(\geq 10 \mathrm{pA}$ ) were at or slightly positive to $-50 \mathrm{mV}$ for calcium-dependent potassium current $(n=8)$ and were at -40 $\mathrm{mV}$ for the calcium-independent potassium current $(n=6)$. Thus, there is insignificant activation of any of the components of potassium currents at voltages in the main part of the interspike interval $(-70$ to $-55 \mathrm{mV})$. This is consistent with the lack of TEA-sensitive potassium current between spikes.

To isolate overall calcium current evoked by the spike waveform, we looked at the difference between recordings made in calcium with TEA and cobalt with TEA, which is shown in Figure 7. This revealed a transient of calcium current that reached a maximum during the falling phase of the action potential. Although the step depolarizations showed inward current followed by outward current, indicative of a substantial calcium-dependent potassium current not blocked by $1 \mathrm{~mm}$ TEA, no outward current was ever seen in response to the spike train command. The lack of current between spikes under these conditions indicates that not only is the net calcium current plus calcium-dependent potassium current near zero between action potentials (Fig. 4I), but each of these currents by itself is also near zero (Fig. $7 E$ ).

To identify the calcium channels producing the transient of calcium current during the spike train, we examined the pharmacology of these currents. To isolate calcium currents, these recordings were made with a CsCl-based intracellular solution and external solution of calcium Tyrode's solution +300 nм TTX. $\omega$-Conotoxin-GVIA (at $3 \mu \mathrm{M}$ ) blocked little or no current in mouse Purkinje neurons (data not shown; $n=3$ ), consistent with previous estimates that $\mathrm{N}$-type current contributes only $\sim 5 \%$ of
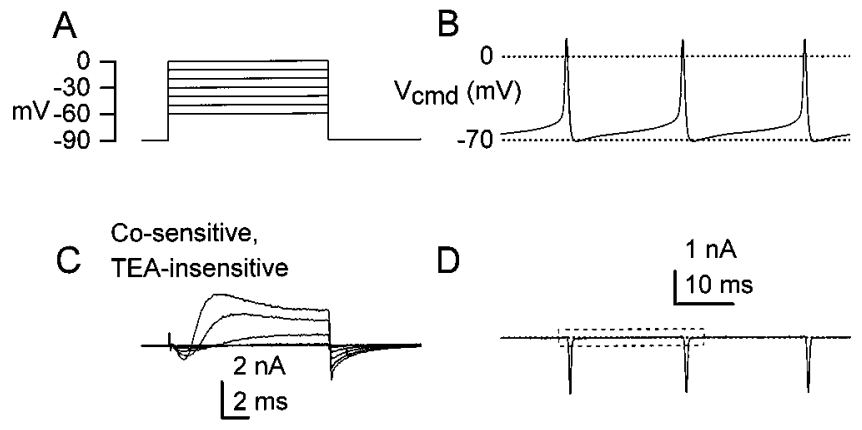

E

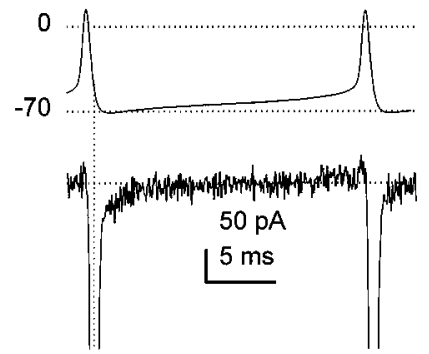

Figure 7. Cobalt-sensitive, TEA-insensitive currents during steps and spikes in a Purkinje cell body. Same cell as in Figures 4 and 5. Calibrations for response to step protocol $(A)$ and spike train protocol $(B)$ are the same as in Figures 4 and 5. $C$, Currents in Figure $5 E$ subtracted from those in Figure $5 C$. $D$, Currents in Figure $5 F$ subtracted from those in Figure $5 D$. Note that all current is inward in response to the spike train protocol, despite the outward current in $C$. E, Magnification of current within dashed lines in $D$, to illustrate the lack of interspike current.

overall high-threshold current in rat Purkinje neurons (Regan, 1991; Mintz et al., 1992). Consistent with this, after application of $100 \mathrm{~nm} \omega$-agatoxin-IVA, there was no further block of current by $1 \mu \mathrm{M} \omega$-conotoxin-MVIIC, which blocks $\mathrm{N}$-type as well as P-type channels (McDonough et al., 1996). We were therefore able to use $\omega$-conotoxin-MVIIC rather than $\omega$-agatoxin-IVA (of which we had limited amounts) to identify P-type current. Recordings were made first in calcium Tyrode's solution and then with $\omega$-conotoxin-MVIIC. Other calcium channel toxins were then added sequentially and cumulatively: $500 \mathrm{~nm}$ mibefradil was used to isolate low-threshold (T-type) calcium current (McDonough and Bean, 1999), and $2 \mu \mathrm{M}$ nimodipine was used to isolate L-type current. Finally, recordings were repeated in cobalt Tyrode's solution to block any remaining calcium current. This sequence avoided effects of mibefradil on P-type current, which are small (McDonough and Bean, 1998), or nimodipine on T-type current, which can be significant (our unpublished results). The individual calcium currents isolated in this way are shown in Figure 8. The characteristics of P-type and T-type currents elicited by step depolarizations (Fig. 8A) are as expected (Regan, 1991; Mintz et al., 1992; McDonough and Bean, 1998): T-type currents have slower tail currents and activate slightly more negatively (Fig. $8 C)$. L-type current and current remaining with $\omega$-conotoxinMVIIC, mibefradil, and nimodipine were both very small in all cells tested.

The calcium currents evoked by the spike train command are shown in Figure $8 B$. The dominant component was a large, rapidly decaying P-type current (Fig. $8 B$ ). In some cells, a much smaller T-type current was also present. In four cells, measuring between -70 and $-65 \mathrm{mV}$, T-type current was $-7 \pm 3 \mathrm{pA}$, decreasing to $-4 \pm 2 \mathrm{pA}$ between -65 and $-60 \mathrm{mV}$. The small 


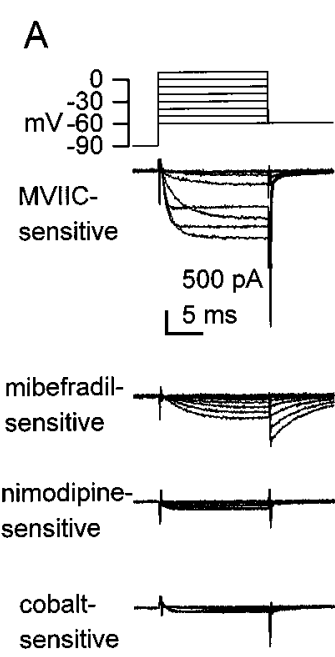

B

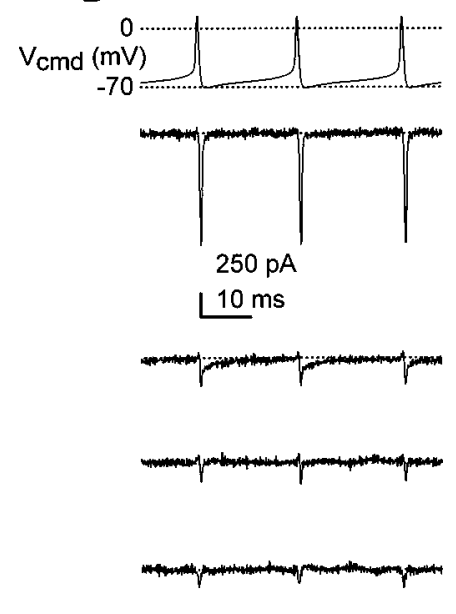

C

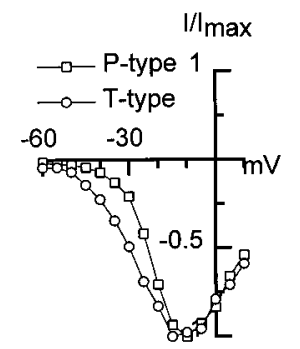

Figure 8. Pharmacologically segregated calcium currents during steps and spikes in Purkinje cell bodies. Currents were recorded with intracellular CsCl. Extracellular solutions contained $300 \mathrm{~nm}$ TTX. Sequence of (cumulative) addition of blockers was $1 \mu \mathrm{M} \omega$-conotoxin-MVIIC, $500 \mathrm{nM}$ mibefradil, and $2 \mu \mathrm{M}$ nimodipine. Then recordings were repeated in cobalt Tyrode's solution to block the small amount of calcium current remaining. $A$, Step protocol (top panel) and evoked calcium currents. MVIIC-sensitive, mibefradil-sensitive, nimodipine-sensitive, and cobalt sensitive designate currents blocked by each agent, as obtained by subtraction of records with and without the blocker. $B$. Spike train protocol (top panel), and currents evoked by the same combinations of blockers as in $A$, for the same cell as in $A$. Vertical gain on currents is twice that in $A$. $C$, Current-voltage relation for MVIIC-sensitive (P-type) and mibefradilsensitive (T-type) current, showing the more negative activation of T-type current. $D$, Mibefradil-sensitive currents evoked by the spike train protocol with different intersweep holding potentials. In the top current trace, the cell was held at $-65 \mathrm{mV}$ for $1 \mathrm{sec}$ between applications of the spike train protocol. In the bottom current trace, the cell was held at $-95 \mathrm{mV}$ for $1 \mathrm{sec}$ between applications of the same protocol. Notice the onset of the mibefradil-sensitive current before the large slow tail in response to the first spike stimulus.

T-type current is caused mainly by steady inactivation during the spike train, because if the cell was held at $-95 \mathrm{mV}$ before applying the spike train (instead of the usual $-65 \mathrm{mV}$ ), slowly decaying currents between spikes were evident (Fig. 8D). However, nearly complete inactivation set in by the sixth spike in the train. Thus, T-type currents are unlikely to dominate the interspike current, although their contribution will be sensitive to the extent of hyperpolarization between spikes.

$I_{\mathbf{h}}$

Spontaneous firing of many excitable cells is promoted by $I_{\mathrm{h}}$, a voltage-dependent current activated by hyperpolarization (Mayer and Westbrook, 1983; McCormick and Pape, 1990; Pape, 1996). $I_{\mathrm{h}}$ is present in Purkinje neurons studied in brain slices (Crépel and
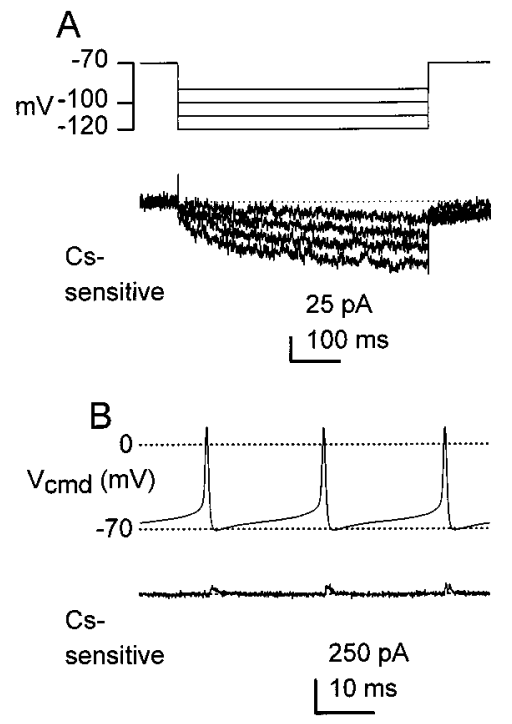

Figure 9. Cesium-sensitive currents in a Purkinje cell body. This is the same cell as in Figures 4-7. A, Step protocol and cesium-sensitive (hyperpolarization-activated) currents obtained by subtraction of recordings in calcium Tyrode's with and without $1 \mathrm{mM} \mathrm{CsCl}$; intracellular $\mathrm{KCH}_{3} \mathrm{O}_{3} \mathrm{~S}$ solution; holding potential $-70 \mathrm{mV}$; steps from -90 to -120 $\mathrm{mV}$, in $-10 \mathrm{mV}$ increments. $B$, Spike train protocol and resulting currents for same solutions as in $A$.

Penit-Soria, 1986). We found that isolated Purkinje neurons also possessed $I_{\mathrm{h}}$. Hyperpolarizing voltage steps elicited characteristic time-dependent currents that grew over a period of hundreds of milliseconds and were blocked by $1 \mathrm{~mm}$ cesium in the external solution (Fig. 9A). The maximal amplitude of $I_{\mathrm{h}}$ current was $-48 \pm 5 \mathrm{pA}$ at $-120 \mathrm{mV}(n=7)$. In response to the spike train protocol, there was no cesium-sensitive current during the interspike intervals (Fig. 9B), consistent with the requirement for more negative voltages (beyond $-80 \mathrm{mV}$ ) for significant activation of $I_{\mathrm{h}}$. The small cesium-sensitive outward currents during the spikes most likely reflect weak block of depolarization-activated potassium currents.

\section{Current-clamp experiments}

We next examined effects of various channel blockers on spontaneous firing. As illustrated in Figure $10 A$, cesium $(1 \mathrm{~mm})$ had no effect on spontaneous firing rates $(102 \pm 4 \%$ of control; $n=12)$, although cesium did block the sag in the membrane voltage in response to hyperpolarizing current pulses, which is characteristic of $I_{\mathrm{h}}$ (Fig. 10B). These recordings also illustrated the high input resistance of the Purkinje cell bodies. In steps from $-65 \mathrm{mV}$ with calcium Tyrode's solution, the input resistance was $900 \pm 75$ $\mathrm{M} \Omega(n=7)$.

To investigate whether the small T-type current evoked under voltage clamp exerts a measurable effect on firing, we applied 500 nM mibefradil to spontaneously firing neurons. In mibefradil, the rate of firing decreased (Fig. 11 $A$ ) and on average was slowed to $72 \pm 3 \%$ of the control frequency in calcium Tyrode's solution $(n=5)$. These results suggest some participation of T-type channels in shaping spontaneous firing. However, we cannot be completely certain that mibefradil affected only T-type calcium channels in the current-clamp experiments. Although mibefradil is highly selective for T-type over P-type calcium channels (McDonough and Bean, 1998), it has not been systematically tested against other kinds of voltage-dependent channels. 
A Ca Tyrode's
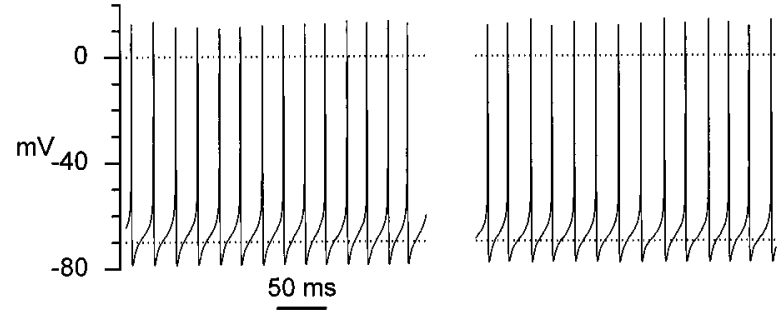

B

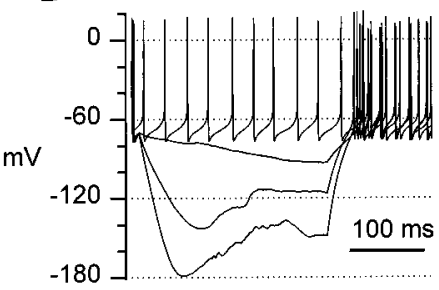

$$
\text { pA }-100]
$$

Figure 10. Spontaneous firing in the presence and absence of cesium. $A$, Spontaneous firing in calcium Tyrode's (left) and in calcium Tyrode's with $1 \mathrm{~mm}$ cesium (right). The spiking frequency changed from 52 to 46 Hz. $B$, Voltage-current relation in the same cell as $A$, in the same solutions. Step hyperpolarizations were given from $0 \mathrm{pA}$ to $0,-20,-60$, and $-100 \mathrm{pA}$ (bottom panels). In the presence of cesium, the hyperpolarization-induced sag in membrane potential was abolished, and there was a slower return to baseline after the offset of the hyperpolarizing pulse.

When all calcium currents (and calcium-activated currents) were blocked by cobalt Tyrode's solution, 17 of 21 cells continued to fire spontaneously (Fig. 11B). On average, cobalt reduced the firing rate to $83 \%$ of control. However, the change in rate was variable and sometimes the firing rate actually increased (range, 34 to $158 \%$ of control); an increase in stimulus-evoked firing rate with nickel block of calcium channels has been reported previously in intact Purkinje neurons (Callewaert et al., 1996). Four of the 21 cells studied ceased to fire in cobalt. On cessation of firing, these cells rested at a relatively depolarized membrane potential of $-46 \pm 1 \mathrm{mV}$. This is consistent with the voltage-clamp results showing that the dominant electrical effect of calcium influx is to activate an outward current, which would promote hyperpolarization. Thus, silencing is not attributable to removal of depolarizing calcium current but rather to depolarization block. In fact, with continuous application of $\leq 10 \mathrm{pA}$ of hyperpolarizing current, three of these cells resumed spontaneous firing, as shown in Figure $11 C$. The fourth cell could be induced to fire a short series of action potentials after brief hyperpolarizations, as shown in Figure $11 D$. Silencing by cobalt had a characteristic profile of spike trough becoming less negative and spike peak potential becoming less positive for several spikes preceding the cessation of firing. This suggests that, in these cells, calcium-dependent potassium current is important for hyperpolarizing the membrane potential sufficiently for substantial recovery of sodium channels. The majority of cells, which maintain spontaneous activity in cobalt, may have enough calcium-independent potassium current to repolarize the cell for sufficient recovery of sodium channels between spikes, or large enough sodium currents so that firing can persist even with a reduced availability of sodium channels.
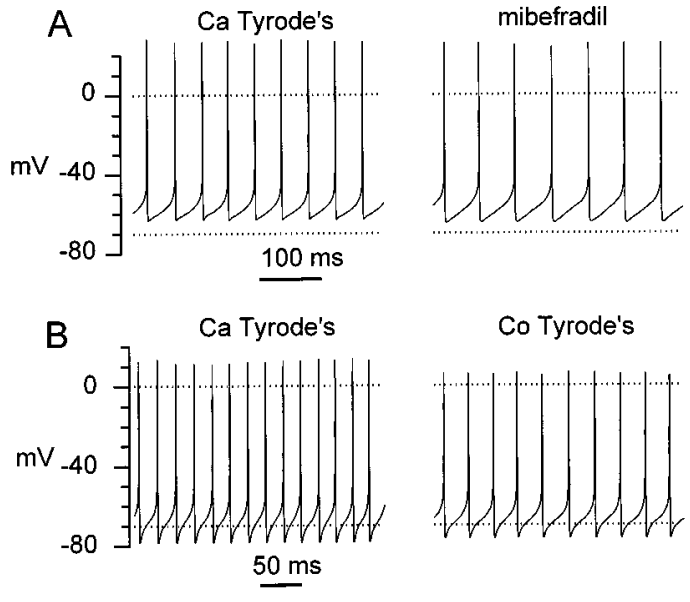

Co Tyrode's
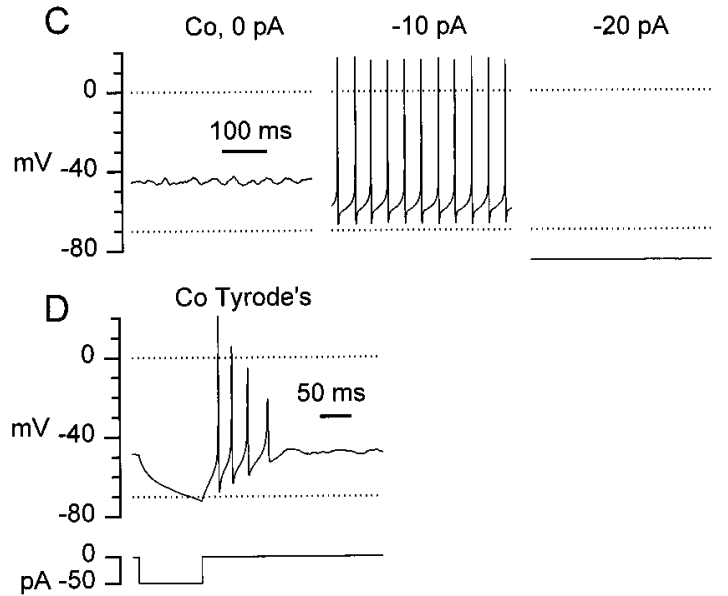

Figure 11. Effects of blocking calcium currents on action potential firing. Traces in $A-D$ are from different Purkinje neurons. $A$, Spontaneous action potentials recorded in calcium Tyrode's and calcium Tyrode's with 500 nM mibefradil, as marked. The firing rate was reduced from $25.5 \mathrm{~Hz}$ in control to $19.5 \mathrm{~Hz}$ in mibefradil. $B$, Spontaneous activity in calcium Tyrode's and cobalt Tyrode's. The frequency of spiking changed from 52 to $35 \mathrm{~Hz}$. Same cell as in Figure 10. C, Responses of a spontaneously active cell that was silenced in cobalt Tyrode's. The cell rested at $-45 \mathrm{mV}$ $(l e f t)$. With a constant injection of $10 \mathrm{pA}$ hyperpolarizing current, the cell fired repetitively and regularly (middle). With injection of $20 \mathrm{pA}$ hyperpolarizing current, the cell was silenced again, resting at $-85 \mathrm{mV}$ (right). $D$, Responses of another spontaneously active cell that was silenced in cobalt Tyrode's. After a $100 \mathrm{msec}, 50 \mathrm{pA}$ hyperpolarization, the cell fired a short train of action potentials, which showed a progressive reduction in the depth of the hyperpolarization and the peak of the depolarization.

As illustrated in Figure 12A, 300 nм TTX blocked firing in all cells tested $(n=10)$. The resting potential in $300 \mathrm{~nm}$ TTX was $-62 \pm 3 \mathrm{mV}(n=10)$, and no underlying fluctuations or oscillations in membrane potential remained. In $300 \mathrm{~nm}$ TTX, depolarizing current did not elicit action potentials, nor did hyperpolarizations produce rebound low-threshold calcium spikes (Fig. 12B).

We also examined the effect of submaximal blocking concentrations of TTX on firing. A dose-response relation for TTX block of peak transient sodium currents under voltage clamp identified the half-maximal blocking concentration to be $2.5 \mathrm{~nm}$, consistent with the estimate of $3 \mathrm{~nm}$ for block of sodium current in guinea pig Purkinje neurons (Kay et al., 1998). Although we did not directly examine the potency of TTX on interspike sodium currents, this is likely to be the same as for peak transient 


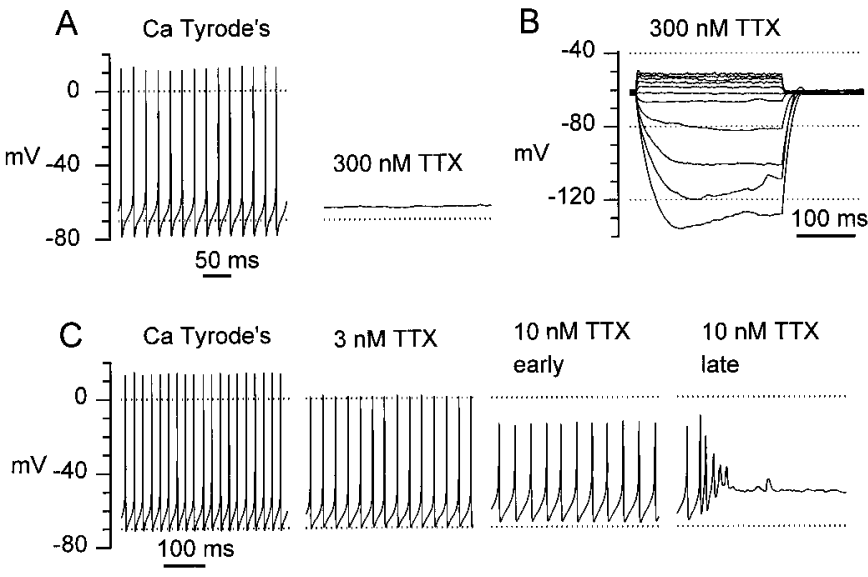

Figure 12. Effects of TTX on spontaneous firing and membrane potential. $A$, Same cell as in Figure 10 and $11 A$. Firing was abolished in $300 \mathrm{~nm}$ TTX, and the cell rested at $-64 \mathrm{mV} . B$, Voltage-current relation in 300 nM TTX; steps from -100 to $+100 \mathrm{pA}$ in $20 \mathrm{mV}$ increments. $C$, Spontaneous firing in calcium Tyrode's, with 0,3 , and 10 nM TTX, as indicated. This cell continued to fire for some time in $10 \mathrm{~nm}$ TTX (early) before silencing and resting at $-51 \mathrm{mV}$ (late).

current, because Kay and colleagues (1998) found identical TTX sensitivity for inactivating and noninactivating sodium currents. All cells still fired spontaneously in $3 \mathrm{~nm}$ TTX ( $\sim 60 \%$ block of available channels), as illustrated in Figure $12 C(n=7)$. The firing rate fell to $70 \pm 6 \%$ of the control rate, and peak membrane potential of the spontaneous spikes decreased by $12 \pm 3 \mathrm{mV}$.

In 10 nм TTX ( $\sim 90 \%$ block), six of seven cells tested were silenced. Figure $12 C$ shows the last two sweeps of firing and silencing in a cell exposed to $10 \mathrm{~nm}$ TTX. The spike peak and trough potentials were sequentially diminished before the cessation of firing. As in the block sometimes induced by cobalt, the silenced cells rested at a relatively depolarized membrane potential of $-53 \pm 2 \mathrm{mV}(n=6)$, significantly more positive than the resting potential $-62 \pm 3 \mathrm{mV}$ in $300 \mathrm{~nm}$ TTX $(p=0.015$; unpaired $t$ test). This suggests that even with $90 \%$ blockade of sodium channels, the remaining sodium current can depolarize the membrane potential by $\sim 10 \mathrm{mV}$.

We next examined whether spontaneous firing could be stopped by an interruption in the cycle of depolarization and repolarization. In calcium Tyrode's solution, we voltage-clamped cells at various potentials for $4-6 \mathrm{sec}$ to allow currents to equilibrate and then released the voltage clamp. After conditioning (voltage-clamped) periods at potentials ranging from -85 to -10 $\mathrm{mV}$ (in $\leq 5 \mathrm{mV}$ increments), all cells resumed firing within a few milliseconds of release of the voltage clamp $(n=7$; spontaneous firing rates ranging from 17 to $121 \mathrm{~Hz}$ ). As illustrated in Figure 13 , the direction and magnitude of membrane polarization on release of the voltage clamp depended on the conditioning potential. Firing resumed regardless of the initial direction of polarization; however, after the most positive conditioning periods, the rate of firing was sometimes slightly reduced at first. Occasionally this change was accompanied by a decrease in the depth of the trough hyperpolarizations. The potential at which the initial direction of membrane polarization reversed on release of voltage clamp was $-48 \pm 1 \mathrm{mV}(n=7)$.

This value is interesting for two related reasons. First, judging from the voltage-clamp results, the overall sum of the different ionic conductances at steady state is probably near a minimum between -40 and $-50 \mathrm{mV}$. In this range of potentials, sodium

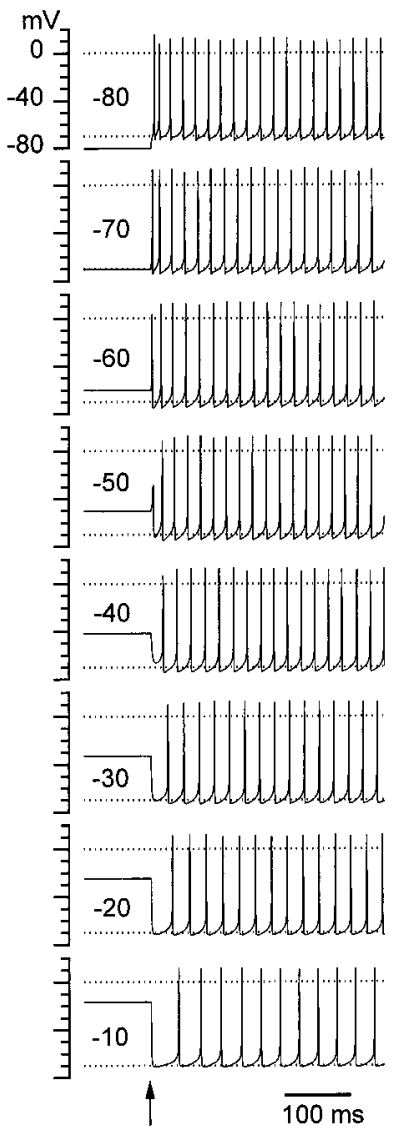

Figure 13. Absence of depolarization block; responses of a Purkinje neuron that was voltage-clamped at (nominally) $-80,-70,-60,-50$, $-40,-30,-20$, and $-10 \mathrm{mV}$ (as labeled) for 4 sec. The clamp was then released at the time point indicated by the arrow, by switching into bridge mode (see Materials and Methods). In all cases the cell resumed firing.

and T-type calcium channels are substantially inactivated, and potassium channels and high-threshold calcium channels are at the foot of their activation curves. Second, under current clamp, the cells that were silenced by moderate blockade of sodium channels (and those few silenced by full blockade of calcium channels) tended to rest in this voltage range. Thus, we investigated whether cells could be silenced by forcing them to particular voltages in this range of potentials. In general, this was not possible. However, near the voltage at which membrane polarization reversed, it sometimes took several hundred milliseconds for firing to resume. In these cases, release of the clamp was followed by an oscillation in membrane voltage that increased in amplitude until firing resumed, as illustrated in Figure 14. When the potential was found with the slowest resumption of firing, the initial direction of voltage change was often variable. In Figure $14 B$, the cell was clamped at $-49 \mathrm{mV}$; in the trial shown in the top trace it hyperpolarized on release of the clamp, and in that shown below, it depolarized. The variability may reflect stochastic behavior of the few channels active at this voltage. On rare occasions, cells ceased firing after clamping at or near the "reversal"; however, such silencing tended to occur late in the recordings and was difficult to distinguish from deterioration of the quality of the recording.

\section{DISCUSSION}

These results show that the high-frequency spontaneous firing of Purkinje neuron cell bodies depends mainly on TTX-sensitive 

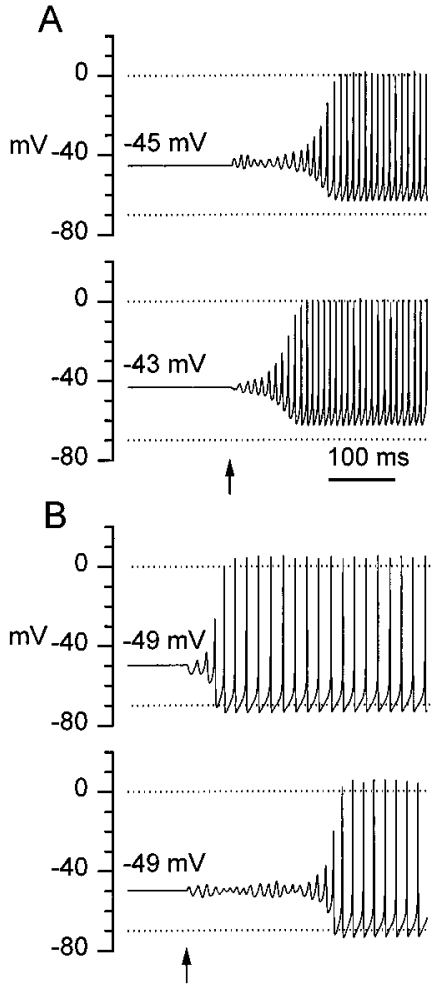

Figure 14. Oscillations of membrane potential in the region of minimal currents. $A$, The cell was clamped at $-45 \mathrm{mV}$ (top panel) or at $-43 \mathrm{mV}$ (bottom panel). The initial direction of polarization on the release of clamp was different and at each of these potentials was consistent across trials (10/10, each condition). Arrow indicates release of clamp. Calibration applies to both $A$ and $B$. B, Same cell as in Figure 13. In both panels, the cell was held at $-49 \mathrm{mV}$ for $6 \mathrm{sec}$ before the clamp was released. Notice the difference in the direction of the initial polarization on release of clamp as well as the difference in the duration of the oscillation.

current flowing at voltages of -70 to $-55 \mathrm{mV}$, as well as a high input resistance and essentially no activation of voltagedependent potassium currents at these voltages.

In contrast to pacemaking in many other central neurons and in heart, the hyperpolarization-activated cation current $I_{\mathrm{h}}$ is not important for spontaneous firing of Purkinje cells, at least in isolated cell bodies. Although the cells possessed $I_{\mathrm{h}}$, voltages during spontaneous firing are never negative enough for significant activation. $I_{\mathrm{h}}$ may be more important in intact neurons, because the channels may be at a higher density in dendrites (Magee, 1998), consistent with much larger $I_{\mathrm{h}}$ currents in intact cells [Crépel and Penit-Soria (1986); also see Budde et al. (1994)]. $I_{\mathrm{h}}$ activation might be promoted by transient hyperpolarization, for example from inhibitory synaptic input, which is ongoing in intact cells (Häusser and Clark, 1997). Nevertheless, the cells can clearly fire at up to $150 \mathrm{~Hz}$ without activation of $I_{\mathrm{h}}$.

\section{Calcium current and calcium-activated potassium current}

T-type calcium current may play a secondary role in spontaneous firing, because mibefradil slowed firing by $\sim 30 \%$ but never stopped it. Like $I_{\mathrm{h}}$, T-type calcium current might play a larger role in pacemaking if more hyperpolarized voltages were reached as a result of inhibitory synaptic input.

Purkinje neurons have large P-type calcium currents. However, with physiological ionic conditions, calcium entry during action potentials is so tightly coupled to activation of calcium-activated potassium current that the net current attributable to calcium entry is outward at all times. Consistent with this, we could not elicit somatic calcium spikes in normal Tyrode's solution when sodium current was blocked with 300 nм TTX; however, reduction of calcium-activated potassium current by 1 mM TEA enabled calcium spikes to be elicited ( $n=6$; data not shown).

The tight coupling between calcium and calcium-dependent potassium currents may contribute to the Purkinje cells' resistance to depolarization block. The slow inactivation of P-type calcium channels (Regan, 1991) would maximize calciumdependent potassium currents with steady depolarizations, thus promoting repolarization. Indeed, when firing sometimes stopped in cobalt Tyrode's solution, it appeared to be caused by block of the calcium-dependent potassium currents, resulting in depolarization block.

Total cobalt-sensitive current was outward or zero at all times during the spike train. However, we did not examine separately the ability of current through T-type and P-type channels to activate potassium current. The slowing of firing by mibefradil is consistent with a net depolarizing effect of T-type current during the interspike interval. This could occur if calcium current through T-type channels were not effective at activating potassium currents.

\section{Potassium currents}

The calcium-dependent and -independent potassium currents that flow during the spike train were both sensitive to $1 \mathrm{mM}$ TEA. Interestingly, in cultured Purkinje cells a developmental increase in the TEA sensitivity of potassium currents coincides with the onset of regular spontaneous firing (Gruol and Franklin, 1987; Yool et al., 1988). Step depolarizations elicited an additional component of TEA-insensitive potassium current (cf. Wang et al., 1991), which apparently has slower activation kinetics. Of various potassium conductances described by single channel recording from Purkinje neurons, some show inactivation (Yool et al., 1988; Gähwiler and Llano, 1989; Gruol et al., 1991), consistent with the rapidly inactivating component of both calcium-dependent and -independent macroscopic potassium currents (Figs. 4, 5).

\section{Sodium current properties}

The interspike depolarization appears to depend mainly on sodium current. Its properties, including TTX sensitivity, are consistent with sodium current at subthreshold voltages previously characterized by long voltage steps and slow voltage ramps (Kay et al., 1998). Both spike-evoked and long-lasting sodium currents seem to be mainly in the cell body of Purkinje neurons (Callaway and Ross, 1997), as originally postulated by Llinás and Sugimori (1980a,b).

In response to the spike train protocol, we measured an average of $-22 \pm 3 \mathrm{pA}$ of sodium current between -70 and -65 . This sodium current represents $<0.1 \%$ of the maximal current that can be elicited, but it is still enough to depolarize the cell fairly quickly. During spontaneous firing, the rate of depolarization between $-70 \mathrm{mV}$ and $-65 \mathrm{mV}$ was $1.2 \pm 0.3 \mathrm{mV} / \mathrm{msec}(n=12)$, which would correspond to a net ionic current of $-30 \pm 8 \mathrm{pA}$ for a cell with a typical capacitance of $25 \mathrm{pF}$. Between -65 and -60 $\mathrm{mV}$, the rate of depolarization was $1.7 \pm 0.3 \mathrm{mV} / \mathrm{msec}$, corresponding to net ionic current of $-42 \pm 8 \mathrm{pA}$. This matches reasonably well with the measured sodium current of $-48 \pm 4 \mathrm{pA}$ between -65 and $-60 \mathrm{mV}$.

Spontaneous firing that depends on subthreshold TTXsensitive sodium but not $I_{\mathrm{h}}$ or calcium current has been described 
previously in suprachiasmatic nuclei neurons (Pennartz et al., 1997) and in dopaminergic amacrine cells (Feigenspan et al., 1998). Purkinje cells fire at rates that are 10-50 times higher than either of these. To maintain such high rates, distinctive kinetic properties of sodium channels in Purkinje neurons may be important. The surge of sodium current immediately after a spike, which may correspond to resurgent current seen with step depolarizations, would speed the initial phase of depolarization. Both the resurgent current and most of the steady current at -70 to $-50 \mathrm{mV}$ are probably from the $S \mathrm{cn} 8 \mathrm{a}$ sodium channel, and mice lacking this channel show inconsistent pacemaking (Raman et al., 1997). Perhaps more important than the depolarizing effect of the resurgent current is its association with rapid, partial recovery from inactivation at relatively depolarized voltages $(12 \%$ recovery in $10 \mathrm{msec}$ at $-40 \mathrm{mV}$ ) (Raman et al., 1997). This quickly restores the availability of sodium channels for spike production.

\section{Interaction of ionic currents to produce spontaneous firing}

A key factor allowing spontaneous firing is the lack of active potassium currents between -70 and $-50 \mathrm{mV}$. Background potassium current is also small, because the input resistance is high. Thus, initially small sodium currents can depolarize the cell to threshold. The steep voltage dependence and high density of sodium channels enable the depolarization to be strongly regenerative and relatively fast. The potassium currents that repolarize the action potential in Purkinje neurons are notable for their very fast deactivation, so that the cells do not hyperpolarize very deeply. Unlike many other neurons, there is not an afterhyperpolarization that approaches $E_{\mathrm{K}}$. The rapid deactivation of potassium current also returns the input resistance to a high value within milliseconds, so that the small interspike sodium current can effectively depolarize the cell for another action potential.

Some repetitive phenomena, like the swinging of a pendulum, can be stopped by temporarily arresting the cycle at a particular position. In principle, spontaneous firing of an excitable cell might require a continuous cycle of interacting voltage-dependent conductances. For example, generation of a full-blown spike might be needed to activate potassium currents sufficient to produce a hyperpolarization deep enough to allow recovery from inactivation of sodium channels. In such a case, any interruption of the cycle might silence the cell. This is clearly not the case in Purkinje neurons, because regular firing always resumed after voltage clamping the cell at any voltage. It is particularly notable that cells do not enter depolarization block. Firing resumed even after voltage clamping the cell at $-10 \mathrm{mV}$ for $4 \mathrm{sec}$, which maximally inactivates sodium channels and partly inactivates potassium channels. After the release of clamp, the remaining potassium current hyperpolarized the membrane such that sodium channels recovered enough to resume spontaneous firing. Thus, the basal state of spontaneous endogenous firing can be quickly restored after large perturbations (e.g., from synaptic inputs) in either direction.

The robustness of firing is also evident in the remarkably small effects of various ionic substitutions and pharmacological manipulations. Even total block of the large calcium currents (and secondary block of even larger calcium-activated potassium currents) usually had little effect on firing rate. Equally surprising, partial block of sodium channels by 3 nм TTX, which blocked $\sim 60 \%$ of sodium channels, reduced the spontaneous firing frequency by only $\sim 30 \%$. Evidently, firing rate has a sublinear dependence on sodium conductance.

\section{Comparison with intact neurons}

The regular spontaneous firing of isolated Purkinje cell bodies is strikingly similar to that of intact Purkinje neurons studied in brain slices when both excitatory and inhibitory synaptic inputs are blocked (Häusser and Clark, 1997). The similarity suggests a primary importance of somatic currents for spontaneous firing, although the firing of intact cells must also be influenced by the voltage-dependent channels present in dendrites (Llinás and Sugimori, 1980a,b; Usowicz et al., 1992; Stuart and Häusser, 1994), as well as by the resistive and capacitative load of the dendritic tree (Jaeger et al., 1997). It has long been appreciated from both experiments (Llinás and Sugimori, 1980a,b; Hounsgaard and Midtgaard, 1988) and modeling (De Schutter and Bower, 1994a,b; Jaeger et al., 1997) that the intrinsic membrane properties of Purkinje neurons are likely to powerfully influence responses to synaptic inputs. The high-frequency spontaneous firing of Purkinje neurons in the absence of synaptic currents, or even dendritic currents, strongly reinforces this idea.

\section{REFERENCES}

Alger BE, Nicoll RA (1980) Spontaneous inhibitory postsynaptic potentials in hippocampus: mechanism for tonic inhibition. Brain Res 200:195-200.

Alonso A, Llinás R (1989) Subthreshold Na+-dependent theta-like rhythmicity in stellate cells of entorhinal cortex layer II. Nature 342:175-177.

Bayliss DA, Li Y-W, Talley EM (1997) Effects of serotonin on caudal raphe neurons: activation of an inwardly rectifying potassium conductance. J Neurophysiol 77:1349-1361.

Bell CC, Grimm RJ (1969) Discharge properties of Purkinje cells recorded on single and double microelectrodes. J Neurophysiol 32:1044-1055.

Budde T, White J, Kay AR (1994) Hyperpolarization-activated $\mathrm{Na}^{+}-\mathrm{K}^{+}$current $\left(\mathrm{I}_{\mathrm{h}}\right)$ in neocortical neurons is blocked by external proteolysis and internal TEA. J Neurophysiol 72:2737-2742.

Callaway JC, Ross WN (1997) Spatial distribution of synaptically activated sodium concentration changes in cerebellar Purkinje neurons. J Neurophysiol 77:145-152.

Callewaert G, Eilers J, Konnerth A (1996) Axonal calcium entry during fast "sodium" action potentials in rat cerebellar Purkinje neurons. J Physiol (Lond) 495:641-647.

Crépel F, Penit-Soria J (1986) Inward rectification and low threshold calcium conductance in rat cerebellar Purkinje cells. An in vitro study. J Physiol (Lond) 372:1-23.

De Schutter E, Bower JM (1994a) An active membrane model of the cerebellar Purkinje cell I. Simulation of current clamps in slice. J Neurophysiol 71:375-400.

De Schutter E, Bower JM (1994b) An active membrane model of the cerebellar Purkinje cell I. Simulation of synaptic response. J Neurophysiol 71:401-419.

DiFrancesco D (1993) Pacemaker mechanisms in cardiac tissue. Annu Rev Physiol 55:455-472.

Doerr T, Denger R, Trautwein W (1989) Calcium currents in single SA nodal cells of the rabbit heart studied with action potential clamp. Pflügers Arch 413:499-603.

Feigenspan A, Gustincich S, Bean BP, Raviola E (1998) Spontaneous activity of solitary dopaminergic cells of the retina. J Neurosci 18:6776-6789.

Fierro L, Llano I (1996) High endogenous calcium buffering in Purkinje cells from rat cerebellar slices. J Physiol (Lond) 496:617-625.

Gähwiler BH, Llano I (1989) $\mathrm{Na}^{+}$and $\mathrm{K}^{+}$conductances in somatic membranes of rat Purkinje cells from organotypic cerebellar cultures. J Physiol (Lond) 417:105-122.

Grace AA, Onn S-P (1989) Morphology and electrophysiological properties of immunocytochemically identified rat dopamine neurons recorded in vitro. J Neurosci 9:3463-3481.

Gruol DL, Franklin CL (1987) Morphological and physiological differentiation of Purkinje neurons in cultures of rat cerebellum. J Neurosci 7:1271-1293.

Gruol DL, Jacquin T, Yool AJ (1991) Single-channel K ${ }^{+}$currents re- 
corded from the somatic and dendritic regions of cerebellar Purkinje neurons in culture. J Neurosci 11:1002-1015.

Häusser M, Clark BA (1997) Tonic synaptic inhibition modulates neuronal output pattern and spatiotemporal synaptic integration. Neuron 19:665-678.

Hodgkin AL, Huxley, AF (1952) A quantitative description of membrane current and its application to conduction and excitation in nerve. J Physiol (Lond) 117:500-544.

Hounsgaard J (1979) Pacemaker properties of mammalian Purkinje cells. Acta Physiol Scand 106:91-92.

Hounsgaard J, Midtgaard J (1988) Intrinsic determinants of firing pattern in Purkinje cells of the turtle cerebellum in vitro. J Physiol (Lond) 402:731-749.

Huguenard J (1996) Low-threshold calcium currents in central nervous system neurons. Annu Rev Physiol 58:329-348.

Jaeger D, De Schutter E, Bower JM (1997) The role of synaptic and voltage-gated currents in the control of Purkinje cell spiking: a modeling study. J Neurosci 17:91-106.

Jahnsen H, Llinás R (1984) Ionic basis for electroresponsiveness and oscillatory properties of guinea-pig thalamic neurones in vitro. J Physiol (Lond) 349:227-247.

Kaneda M, Wakamori M, Ito M, Akaike N (1990) Low-threshold calcium current in isolated Purkinje cell bodies of the rat cerebellum. J Neurophysiol 63:1046-1051.

Kay AR, Sugimori M, Llinás R (1998) Kinetic and stochastic properties of a persistent sodium current in mature guinea pig cerebellar Purkinje cells. J Neurophysiol 80:1167-1179.

Latham A, Paul DH (1971) Spontaneous activity of cerebellar Purkinje cells and their responses to impulses in climbing fibres. J Physiol (Lond) 213:135-156.

Llinás R (1988) The intrinsic electrophysiological properties of mammalian central neurons: insights into central nervous system function. Science 242:1654-1664.

Llinás R, Sugimori M (1980a) Electrophysiological properties of in vitro Purkinje cell somata in mammalian cerebellar slices. J Physiol (Lond) 305:171-195.

Llinás R, Sugimori M (1980b) Electrophysiological properties of in vitro Purkinje cell dendrites in mammalian cerebellar slices. J Physiol (Lond) 305:197-213.

Magee JC (1998) Dendritic hyperpolarization-activated currents modify the integrative properties of hippocampal CA1 pyramidal neurons. J Neurosci 18:7613-7624.

Magistretti J, Mantegazza M, Guatteo E, Wanke E (1996) Action potentials recorded with patch-clamp amplifiers: are they genuine? Trends Neurosci 19:530-534.

Mayer ML, Westbrook GL (1983) A voltage-clamp analysis of inward (anomalous) rectification in mouse spinal ganglion sensory neurones. J Physiol (Lond) 340:19-45.

McCormick DA, Pape H-C (1990) Properties of a hyperpolarizationactivated cation current and its role in rhythmic oscillation in thalamic relay neurones. J Physiol (Lond) 431:291-318.

McDonough SI, Bean BP (1998) Mibefradil inhibition of T-type calcium channels in cerebellar Purkinje neurons. Mol Pharmacol 54:1080-1087.
McDonough SI, Swartz KJ, Mintz IM, Boland LM, Bean BP (1996) Inhibition of calcium channels in rat central and peripheral neurons by $\omega$-conotoxin MVIIC. J Neurosci 16:2612-2623.

Mintz IM, Adams ME, Bean BP (1992) P-type calcium channels in rat central and peripheral neurons. Neuron 9:85-95.

Nam SC, Hockberger PE (1997) Analysis of spontaneous electrical activity in cerebellar Purkinje cells acutely isolated from postnatal rats. J Neurobiol 33:18-32.

Pape H-C (1996) Queer current and pacemaker: the hyperpolarizationactivated cation current in neurons. Annu Rev Physiol 58:299-328.

Pennartz CM, Bierlaagh MA, Geurtsen AMS (1997) Cellular mechanisms underlying spontaneous firing in rat suprachiasmatic nucleus: involvement of a slowly inactivating component of sodium current. J Neurophysiol 78:1811-1825.

Raman IM, Bean BP (1997) Resurgent sodium current and action potential formation in dissociated cerebellar Purkinje neurons. J Neurosci 17:4517-4526.

Raman IM, Sprunger LK, Meisler MH, Bean BP (1997) Altered subthreshold sodium currents and disrupted firing patterns in Purkinje neurons of Scn8a mutant mice. Neuron 19:881-891.

Regan LJ (1991) Voltage-dependent calcium currents in Purkinje cells from rat cerebellar vermis. J Neurosci 11:2259-2269.

Salin PA, Prince DA (1996) Spontaneous $\mathrm{GABA}_{\mathrm{A}}$ receptor-mediated inhibitory currents in adult rat somatosensory cortex. J Neurophysiol 75:1573-1588.

Song JH, Narahashi T (1996) Modulation of sodium channels of rat cerebellar Purkinje neurons by the pyrethroid tetramethrin. J Pharmacol Exp Ther 277:445-453.

Stuart G, Häusser M (1994) Initiation and spread of sodium action potentials in cerebellar Purkinje cells. Neuron 13:703-712.

Usowicz MM, Sugimori M, Cherksey B, Llinás R (1992) P-type calcium channels in the somata and dendrites of adult cerebellar Purkinje cells. Neuron 9:1185-1199.

Uteshev VV, Stevens DR, Haas HL (1995) A persistent sodium current in acutely isolated histaminergic neurons from rat hypothalamus. Neuroscience 66:143-149.

Wang Y, Strahlendorf JC, Strahlendorf HK (1991) A transient voltagedependent outward potassium current in mammalian cerebellar Purkinje cells. Brain Res 567:153-158.

Williams JT, North RA, Shefner SA, Nishi S, Egan TM (1984) Membrane properties of rat locus coeruleus neurones. Neuroscience 13:137-156.

Yool AJ, Dionne VE, Gruol DL (1988) Developmental changes in $\mathrm{K}^{+}$. selective channel activity during differentiation of the Purkinje neuron in culture. J Neurosci 8:1971-1980.

Yung WH, Häusser MA, Jack JJB (1991) Electrophysiology of dopaminergic and non-dopaminergic neurones of the guinea pig substantia nigra pars compacta in vitro. J Physiol (Lond) 436:643-667.

Zaza A, Micheletti M, Brioschi A, Rocchetti M (1997) Ionic currents during sustained pacemaker activity in rabbit sino-atrial myocytes. J Physiol (Lond) 505:677-688. 